\title{
Leadership Question and the Rhetoric of Free and Fair Election: A Prognosis of 2007 and 2015 Elections in Nigeria
}

\author{
Dr. BADMUS, Bidemi Gafar
}

\begin{abstract}
The debate on the issue of free and fair election has dominated public discourse by scholars and observers of Nigerian politics due to controversial nature of election and democratic process in Nigeria. However, the 2007 and 2015 elections presented a unique case of electoral politics in Nigeria as both elections were conducted under different political leadership and INEC headship with different approaches to political power and election. This study argues that, what makes the difference between the 2007 and 2015 presidential elections in Nigeria, are leadership disposition to power, the rule of law and whether they are interested in recontesting election or not: these are critical factors that has either boosted or marred the quality of election and determined level of effectiveness or ineffectiveness of INEC in both 2007 and 2015 elections, rather than the over-exaggeration of INEC chairman's integrity, initiatives and professional competency in both elections.
\end{abstract}

Keywords: Democracy, election, free and fair election, political leadership

\section{INTRODUCTION}

Since post independent period in Nigeria, electoral contest has remained the major obstacle to political stability and democratic consolidation. Suffice to say is that apart from the 1993 general elections, which was considered the most free and fair elections in Nigeria's political history, the previous elections dated back from 1959 elections and the entire Fourth Republic elections in Nigeria have posed serious threat to democratic stability and the country unity at large due to unprecedented level of electoral frauds and the aftermath effect of post electoral violence.

This situation was further provoked by disenablement of rational planning and deployment of resources by centrifugal politics, primitive accumulation inclinations of state officials, pervasive corruption, and absence or ineffectiveness of institutions of oversight (Osaghae 2002). The quest for free, fair and credible elections in Nigeria has remained ongoing struggle among the concern stakeholders, victims of electoral frauds and majority of the populace in Nigeria. However, the will and self serving interests of the emerging political elites in Nigeria constitute a big obstacle to such struggle. It is important to note that, most elected leaders in Nigeria have emerged through manipulated process of unfree, unfair, and non credible election, therefore they are vehemently struggling to maintain the status-quo.

The 2007 was considered as very important period in Nigeria's democratic history, unlike the previous experiments to transfer government from one democratically elected government to another which collapsed midway (like the First and Second Republics) or the transition that was truncated at the threshold of its completion (the aborted Third Republic), the 2007 transition at least for the first time, the elected government uninterrupted transited power to another democratically elected government. Meanwhile, it would have been better if the process of such transition were transparent and fair instead of blatant and unprecedented rigging especially, by the ruling parties despite improved atmosphere of election made possible by lesson learnt from the two previous elections (1999 and 2003 elections).

More importantly, the 2007 election marked a watershed in Nigeria political history: the election was considered the worse elections ever conducted in Nigeria. This was further supported by European Union-Election Observation Mission (EU-EOM) final report on 2007 elections in Nigeria; that these elections have not lived up to the hopes and expectation of Nigerian people and its process were not credible because of gross irregularities, fraud, rigging and high level of political violence. In most cases the blames were directed towards the INEC Chairman as the major conspirator in the rigging process that favoured the incumbent party. 


\section{Dr. BADMUS, Bidemi Gafar}

Whereas, the 2015 general elections were generally viewed positively by many stakeholders in Nigeria, particularly, by general public, media, local and internal election observers: specifically, as the election broke the yoke of sitting tight syndrome of the incumbent government in Nigeria for the first time. Succinctly put, 2015 elections was described as a landmark in the history of election in Nigeria by both local and international observers such as Transition Monitoring Group (TMG), International Republican Institute (IRI), EU-EOM and National Democratic Institute (NDI) among others observers.

Therefore, it is instructive to ask, what are the prime factor(s) that account for the failure of the 2007 general elections when compared with the last concluded 2015 general election in Nigeria?, put differently, why was the 2015 elections rated positively and credibly given the circumstances that surrounded the pre-election period in 2015 ?

The significance departure from embedded decadence in the 2007 general elections and the emergence of credibility in 2015 elections made it imperative for study of this nature to examine how the two regimes of former President Olusegun Obasanjo and President Goodluck Jonathan on one hand, and two leaderships of Independent National Electoral Commission (INEC) in 2007 and 2015: Professor Maurice Iwu and Professor Attairu Jega on another hand have impacted on the conduct of election in Nigeria respectively. This paper is divided into five sections; introduction, conceptual clarification, the overview of the 2007 and 2015 elections: locating the lacuna, leadership question and the implications for free and fair election, conclusion and way forward.

\section{Conceptual Clarification}

\subsection{Democracy}

Democracy is a contested concept, which has no settled definition rather there are rival definitions and models of democracy (Beetham 1994; Inkeless, 1991). Democracy is of great interest to every political scientist for the governance of man because it holds out great hopes for the salvation of mankind in general and of Africa in particular Awa, (1992). For Toyo (1994) democracy implies acceptance of the basic equality of men as human and basic responsibility of all adult men and women for their own destiny. He further maintain that there cannot be a genuine democracy in a country where citizen are grossly unequal in wealth and the poor who are inevitably the majority are dependent on the wealthy.

Meanwhile, Lewis (1965) posited that, democracy implies that all who are affected by a decision should have the chance to participate in making that decision either directly or through chose a representative. He concluded that if only the winning parties makes all the governmental decisions and that the losers only criticized but not govern, then democracy is meaningless. Because to exclude the losing groups or parties from participation in decision making clearly violate the primary meaning of democracy.

In same vein, Schumpeter (1976) conceived democracy as a political method that is an institutional arrangement for arriving at political legislative and administrative decisions by vesting certain individuals the power to decide on all matters as a consequence of the successful pursuit of the people's vote. To Schumpeter the essence of democracy was the emphasized on the ability of citizens to replace one government by another and hence protect themselves from the risk of political decision makers transforming themselves into an immovable. Although democracy could serve a vanity of ends, such as the pursuit of social justice, equality, welfarism, but he caution people not to confuse these ends with democracy itself.

However, given the above disagreement on the definition of democracy, the conventional wisdom deduced from all the perspectives is the important role of election in a democratic system. This suggests that election and democracy are inextricably interwoven (that is, one cannot be achieved without the other).

\subsection{Election}

The important role of election in a democratic system cannot be overemphasized, because it shapes the mode of political competition and serve as a major determinant of who get what, when and how. According to Joseph (1987: 18) election is describe as important starting point for the existence of democracy, making it possible for democratic government to be 'by person freely chosen by and 
responsible to the governed. Similarly, Wanyande (1987: 80) stressed that elections represent a way of making a choice that is fair to all - one that leaves each member of the electorate reasonable hope of having his alternative elected. An election is therefore an empirical demonstration of a citizen's liberty and political choice. On the other hand, Ntalaja (1997) argued that the essence of liberal democracy has been increasingly reduced particularly, in Africa to the conduct of election and introduction of multipartyism". To International Encyclopedia of Social Science election is defined as one procedure of aggregating preferences of a particular kind.

In same vein, Ayoade (1999) describes election as the process of actualizing representative democracy. It is a method of selecting a few people from large group such that the few people are a representative sample of the large group. To him, the few elected are supposed to be the mirror image of their electors in term of political programmes and beliefs. To Nnadozie (2004) election is "a medium and universally accepted means through which by voting, individuals and groups are openly and methodologically chosen to represent a body or community in a larger entity or governance.

In the opinion of Graft (1979) elections are expected to promote majority rule through the establishment of legitimate government and the exercise of popular control over the leaders of a nation. Importantly, the point of convergence in the above definitions rest on the value placed on election as a major way of actualizing democracy.

\subsection{Free and Fair Election}

Free and fair election is sine qua none to genuine democracy. Thus, people may enjoy freedom to live, to vote and be voted for, form associations, to education, however, if the will of electorates is subverted through election rigging and manipulations, democracy maybe at the risk of collapse.

According to the United Nations (1994) free and fair election were broadly discussed in the legal, technical and human rights aspects of election through specified number of fundamental criteria for free and fair elections as contained in some of the international instruments for promotion and protection of human rights such as Universal Declaration on Human Rights, the article 19 of International Covenant on Civil and Political Rights, the International Bills for Human Rights. These criteria include the following; freedom of opinion, freedom of expression and information, freedom of assembly, independent judiciary, principle of non-discrimination, equal universal and nondiscriminatory suffrage, non-discrimination and positive measures, one man, one vote among others. Therefore, once all the criteria listed above are satisfied then election could be adjudged as free and fair vice versa the other way round.

Similarly, Ayoade (1999) an election is the sovereign right of the people and manipulating it is a violation of the aggregate sovereign right of the people. Thus, free and fair election connote an electoral process in which there is no hindrance to popular participation both among individual voters and political parties and in which the electoral procedure and electoral law are apply justly and equitably without fear or favourism.

As observed by Omoniyi (1999) election could be free and fair, yet it may not be credible: in his view, the 1999 elections was not credible, because the 'political environment required to encourage the believability of the outcome was absent (Sunday Concord, 11 April 1999). Therefore, for election to be free and fair, electoral management body should handle the free and fair aspect of election, while another independent body should handle the credibility of election.

\subsection{Leadership}

Most literatures have analyses leadership within several contexts of certain elements that are necessary ingredients in the definition of political leadership. These elements include: the personality and traits of a leader or leaders, including his or her ethical and cultural character; the traits and ethical-cultural character of the followers with whom the leader interacts; the societal or organizational context in which the leader-follower interaction occurs. These elements according to Peele (2005) involve the nature of the leader's interpretive judgment, (ability of the leader to interpret a given situation and act in such a way that meets the expectation of the followers); the material as well as immaterial means that the leaders use to attain their ends and the technique that leaders adopt to gain the willing support of their followers. 


\section{Dr. BADMUS, Bidemi Gafar}

In the same vein, Seteolu (2004) identified such elements as trait, behaviour, attribution, charisma, transformation and vision: The trait theory identifies the attributes of confidence, determined and decisive ambition and energy, the desire to lead, honesty and integrity, intelligence and knowledge. In this circumstance, the leader initiates the structure, seeks new ideas, generates and implements change. The attribution theory sees leadership as an allusion to how the 'followership' characterizes the leaders, while the charismatic theory is hinged on the features of self-confidence, vision, and ability to articulate the vision; strong convictions about the vision, and extra-ordinary behaviour. Put differently, the charismatic leader is viewed as an agent of radical change rather than the status quo.

In the opinion of Chemers (2002), leadership is a process of social influence by which a person influences others to accomplish an objective and directs the organisation in a way that makes it more cohesive and coherent. Given Chemers' definition a leader therefore is expected to demonstrate qualities, which embrace but not limited to good character, vision, tact, prudence, and ability to lead by example because people basically ascribe leadership to those who they feel can most enable them achieve important goals or objectives. According to Seteolu (2004), the leadership question, all over the world, is often hinged on the interface of structure and behaviour, the dialectic of persons in relation to institutions. Beyond defining leadership as a process by which one individual influences others on the level of the pursuit of group behaviour, the extant literature on the concept offers a theoretical and philosophical basis for explaining the motives and character of the governing elite in any society.

Despite this lack of conceptual precision, Lewin and others have identified the central element of the term democratic leadership as behavior that influences people in a manner consistent with and conducive to basic democratic principles and processes, such as self-determination. Inclusiveness, equal participation, and deliberation (Dahl, 1989; Fishkin. 1991))

\section{OVERVIEW OF THE 2007 ELECTIONS IN NIGERIA}

The 2007 election is the third elections to be held since the transition from military to civilian rule in 1999 and is widely considered to be a crucial test of the commitment of Nigerian government and its people to democratic consolidation. For the first time since independence, Nigeria recorded uninterrupted transferred of political power from one civilian president to another. Given the problematic nature of the 2003 elections, the 2007 elections provided an opportunity to strengthen public confidence in electoral process and democratic governance based on the improvement in 2006 electoral act which remedies some of the anomalies in the 2002 electoral act.

However, in the face of high hopes and expectations of Nigerian people and international community, that the 2007 elections would eventually leads to democratic consolidation in Nigeria. The reverse was the case, as the environment of pre-elections activities cum election day were marred with intense violence, unsettled court cases, internal and external parties crisis resulting from irregularities in parties primaries, seat tight syndrome of incumbent government, unhealthy political campaign, inadequate and weak electoral laws, INEC internal and external problems such as issues of trueindependent, financial autonomy, and operational ineffectiveness among others challeges. Suffice to say is that the environment of 2007 elections was unhealthy for democratic process and electoral conduct, not to talk of democratic consolidation.

It is instructive to note that, several factors have been linked to the failure of 2007 general elections. Some of the factors are as follows;

\subsection{Vague and Weak Electoral Laws}

It has been argued that a country's legal and political culture is critical to how the electoral process in specific countries serves to anchor democracy in public approval and confidence and in legitimizing political succession (Jinadu 2008). From the foregoing, it become clear that the qualities of electoral laws determine to a greater extent how free and fair election would be supposedly all actors keeps to the rules that govern elections. And this also suggests that election can never be better than the qualities of law that govern its process.

The 2007 elections are regulated by the 1999 constitution and Electoral Act of 2006 together with the administrative rules and regulations issued by INEC. In an effort to ensure that 2007 elections were better conducted than that of the 2003 elections, the 2006 Electoral Act was adopted to redressed some lapses in 2002 Electoral Act that governed 2003 elections. However, the 2006 Electoral act 
further compounded or left unresolved some critical problems before the conduct of 2007 elections. Such issue include: issue of independent candidates, true independent and autonomy of INEC, deficiency relates to the existing law which allows contestants in an election petition to be sworn-in before the determination of the petition. President retaining the power to appoint the INEC chairman, twelve National Commissioners and the thirty seven Resident Electoral Commissioners among others.

Given the lapses left unaddressed in the 2006 Electoral Act, the 2006 Electoral Act was considered weak and inadequate legal framework for the 2007 elections: instead of entrenchment of INEC financial autonomy, rather, it tied the fate of INEC in term of funding to the Executives discretion. It also failed to make it clear the prohibition on the use of state fund by the incumbent government for their political campaign. There was no provision for civil society or voters to file a petition against any political party or contestant who stole public mandates in elections.

The lack of procedures and time limits in the Electoral law for handling complaints related to substitution or disqualification of candidates prompted the filing of many cases in the courts just a few days, before the elections. Some cases remained pending at the time of the election. This created uncertainty about the final list of candidates and was not conducive to clear voter choice at the elections. (EU -EOM 2007) Although electoral laws are very crucial and cover a great deal of ground when viewed against the backdrop of the laws that governed the 1999 and 2003 elections. There are elaborate provisions about electoral malpractice and violence as well as opportunities for redress in cases of contrived exclusion of candidates (Aiyede 2007).

\subsection{Political Violence}

Elections in liberal democracies are typically different from those in authoritarian and dictatorial political system, by virtue of their ex ante inter-determinancy: by which is meant the possibility of today's winners becoming tomorrow's losers and today's losers becoming tomorrow's winners (Przeworski, 1991:10). The distinctive feature of democratic elections lies, therefore, in the possibility and prospects of the electoral defeat of incumbents holding elective public political office (Jinadu (2008)

Based on the foregoing, it could be argue that the principle of ex ante inter-determinancy is seriously lacking in Nigerian politics. This has become evident in most of the political ills and crisis that have bedevilled democracy in Nigeria since independence such as; seat tight syndrome, 'do or die' electoral contest, primitive accumulation, winners' takes all approach, over centralization of power and resources, political mobilization along ethnic and religious cleavages, high premium place of political offices... (Joseph, 1983; Ake, 1994; Gboyega, 2003; Toyo, 1994)

As rightly captured by Ehindero (2007), the culture of thuggery which involves; the physical battles between supporters of different parties and candidates and the hacking of people with dangerous weapons are part of the mechanisms for electoral violence. He further stressed that the intensity of electoral conflict is often fuelled by the widespread belief that the other party is planning to rig elections, has hired thugs and accumulated dangerous weapons and arms to actualize its plans, failing which it will unleash violence on its opponents. It was not uncommon to see politicians on their campaigns tours accompanied by a vehicle full of thugs brandishing their weapons.

Election related violence has become a major issue of concern in every election in Nigeria: as the election drew nearer the incidents usually violence increased. The EU-EOM reports indicate that at least 200 people including candidates and police were killed in election related incidents, which is unacceptable with respect to right to life and democratic process. (EU-EOM 2007). Despite, the promise of zero tolerance of political violence by the security agencies, and the huge amount invested in the purchase of arms and ammunitions by Federal Government to deter violence, both the security agencies and the government did not appear to take decisive steps to address the situation and hold perpetrators to account.

\subsection{Unsettled Court Disputes in the Pre-election Period}

Several disputes relating, in particular, to the power and function of INEC and the nomination, substitution and disqualification of candidates either by political parties or INEC brought the judiciary into centre stage in the electoral process. However, the lack of adequate procedures and time limits for initiation and adjudication of complaints and appeals prior to election day resulted in a number of 


\section{Dr. BADMUS, Bidemi Gafar}

dispute being dealt with by the courts just few days before the elections. Some court disputes remained pending until after election. This situation resulted into confusion and anxiety among voters to freely making their choice during elections as the pictures and names of some aspirants were omitted from the ballot papers. However, the delay in adjudication of pre elections disputes which automatically denied some contestants their constitutional right to contest in a popular election thus provoked the use of extra-judicial means of dealing with the situation.

\subsection{Intra Parties Conflicts}

As a matter of fact, the condition of the parties, in a political system, is the best possible evidence of the nature of any democratic regime. (Anifowose, 2004) He further argued that a sustainable democratic order in Nigeria depends upon the ability of the parties to manage successfully the conflicts both within and among the existing political parties. However, in Nigeria the nature and intensity of party competition particularly in 2007 and generally in the Fourth Republic had invariably engendered tremendous bickering, political uncertainties and disorder in many parts of the country. Since the inception of Fourth Republic party conduct has witnessed frequent discords, unresolved political issues, recrimination, flagrant breach of party rules, carpet-crossings, and resurgence of factional cleavages within the parties, which have continue to threaten the functioning of democracy in Nigeria. Most of the conflicts that engulfed party conduct in 2007 elections were the nomination of candidates by political parties which was characterized by forceful imposition and selection of candidates rather than election. (Iman 2008).

More often than none, party primaries took place outside of clear democratic rules. This resulted in a number of court cases which involved politicians who won their internal party primary but were not nominated by the political party, or were nominated but subsequently substituted by the party leadership have challenged their removal as the party's candidates before the law court (Bello, 2008). For instance, in some cases, where candidates challenge their substitution political parties responded by expelling such candidates from the party on the basis of anti-party allegation. The aggrieved members of political parties also responded either through coalition to form a new party or through violence means of stampeding the victory of their formal party in their local strong-hood.

\subsection{Unprepared Electoral Management Body}

Apart from internal administrative problems, the major impediments to INEC performance and credibility are the issue of true independent and funding. The present legal framework (1999 constitution, section 154 (5) empower the president to appoint the Chairman, other national commissioners and the (37) thirty seven Resident Electoral Commissioners in consultation with the council of state. This provision obviously gives no autonomy to the commission and calls to question its independence. For instance, the countdown to the 2007 elections witnessed undue interference by the executive which resulted in undue, selective and last minute disqualification of candidates by INEC in favour of the ruling party. (Simbine et al 2008).

Another impediment to effective performance of INEC is that of funding. Although the Electoral Act 2006 promulgated financial independence by INEC, the envisage INEC fund was not established and INEC remained dependent on the president's office for approval of its expenditure as evidenced when about 60 per cent of the electoral grants for the 2003 elections were released in December, 2002 barely three months to the election. 20 percent of the grant was released in March 2003, barely a month to the elections (INEC 2003). Some of the INEC cheques were not cleared even until October 2006. (EU-EOM 2007).

There are also internal administrative problems confronting INEC in the conduct of elections. Preparations by INEC to conduct the elections were delayed throughout the process: there was delay of two months to complete the voter registration exercise which affected the production and distribution of permanent voter cards. In both 14 and 21 April 2007 elections, the distribution of ballot papers was also delayed which had a serious impact on both polling days activities. The late recruitment of ad-hoc staff by INEC, reportedly for security reason, delayed the thorough training of ad-hoc staff which also affected the conduct and quality of elections. There were limited national voter education media campaign by INEC and in most cases it commenced only seven days prior to the 14 April election day. The electronic direct data capturing process used in the exercise was hampered by a delay in establishing sufficient registration centres in the field and experienced technical and power supply problems. There were cases of registration of underage voters, double 
registration and instances where INEC officials rented out the voter registration machine to politicians for monetary reward.

According to the Electoral Act 2006, any person who double registers commits an offence and he/she is liable, on conviction, to a fine up to $\$ 100,000$ or one year imprisonment or both (Electoral Act 2006 part III section 17 (2)) in INEC report, 10 million double entries were deleted from the register in 2003 but no single person was prosecuted. INEC appears too weak in providing legal oversight over campaign spending and scrutiny. While the electoral framework includes restrictions on excessive campaign spending to prevent disproportionate expenditure this was not thorough supervised and enforced by INEC as the incumbent governments both at federal and state levels diverted government funds for their personal political campaign, therefore creating unequal conditions for contestants in term of campaign finance.

\section{OVERVIEW OF THE 2015 ELECTIONS IN NIGERIA}

Nigeria's 2015 general elections were the fifth elections since the country returned to civil rule in 1999. The elections were originally scheduled for the 14th and the 28th of February, however, these dates were changed following security concerns raised by the National Security Adviser, Sambo Dasuki. The elections subsequently took place on the 28th of March (for the presidency and the National Assembly) and on the 11th of April (for state governors and State Houses of Assembly. Although several amendments aimed at improving the legal framework for the 2015 general elections were proposed, the National Assembly could not complete the amendment process before the elections took place. The National Assembly only submitted the bills seeking to amend the Constitution and Electoral Act to President Goodluck Jonathan for his assent in mid-March 2015, a few days before the elections. In the end, the existing legal framework proved an adequate basis for the conduct of the elections in accordance with international democratic principles and with the international instruments ratified by the Federal Republic of Nigeria.

\subsection{Security Concern}

There were grave concerns over the conduct and possible outcome of the elections by concerned citizens and the international community. A former Minister of Foreign Affairs, Prof. Bolaji Akinyemi appealed to the major contestants of the presidential election to sign a Memorandum of Understanding (MOU) that will commit them to control their supporters against violence after the 2015 general elections (Punch, December 22, 2014). Similarly, the National Peace Committee for the 2015 General Elections led by former military ruler, General Abdulsalami Abubakar (rtd) facilitated peace accord between General Buhari (rtd) and President Jonathan (Punch, March 26, 2015). Concerned that Nigeria could burst into flames, America's Secretary of State, John Kerry flew to Lagos to discuss about the 2015 elections with President Jonathan and General Buhari (retd) respectively (New York Times, January 25, 2015).

The election fever got to its peak after the Independent National Electoral Commission (INEC) announced the postponement of the general elections due to security challenges in the Northeastern zone. The presidential election was shifted from February 14 to March 28, while the governorship and state legislative elections will hold on April 11, 2015 (Vanguard, February 8, 2015). According to INEC, Nigeria's electoral body, 68, 833, 476 Nigerians will be eligible to vote in the 2015 general elections (This Day, 2015). Out of the over 68 million registered voters, about 56, 431, 255 people collected their Permanent Voters Cards (PVCs) as indicated by INEC (Vanguard, March 24, 2015).

As part of preparations for the 2015 elections, INEC implemented several reforms including a comprehensive restructuring of its bureaucracy, the development of new communications and gender policies, and an overhaul of its operational and logistics strategy through the introduction of three core innovations: the Election Project Plan (EPP), the Election Management System (EMS), and the Business Process Review (BPR). The extent to which the implementation of these reforms helped to improve election management during the 2015 elections has not been determined, but the myriad challenges faced by INEC in conducting the 2015 elections raise doubts about their effectiveness.

\subsection{Operational and Logistic Challenges}

There were severe difficulties during the elections due to several operational and logistic lapses which led to the late opening of poll stations across the country. This was compounded by the difficulties 


\section{Dr. BADMUS, Bidemi Gafar}

experienced in the use of card readers for the voter accreditation process. Malfunctioning card readers in several polling units led to further delays stretching the voting process in some places to very late into the night. The seriousness of the card reader failure forced INEC to change elections guidelines and allow election officials to manually accredit voters. Though this response was intended to expedite accreditation, it removed the safeguard of electronically checking for authentic PVCs and opened the process to possible manipulation.

For instance, Hassan Zaggi (2015), in a media article, titled: "Transparent but flawed presidential election" posit that: Some of the noticeable faults of the presidential elections, as observed on the day of the election at the polling units monitored, include: late arrival of electoral materials; malfunctioning of Card Readers; insufficient and, in some cases, none availability of electoral materials; overcrowding in polling units, and voting throughout the night which exposed the voters to high risk. There were many faults according to findings that have ended up disenfranchising many voters in many parts of the country. (Citizens' Advocate, April 19, 2015:18).

\subsection{Lack of Adequate Preparation by Election Management Body}

Evidently, the electoral body was confronted with inadequate preparation problems including the late arrival of its officials, inadequacy of both the officials and election materials in some units, electionday recruitment of ad-hoc personnel to replaced the absentees ad-hoc who did not show up due to anticipated fear of electoral violence, lack of proper arrangement for conveying officials and materials to polling stations in view of the restrictions of vehicular movements, and lateness in commencement of elections.

The conventional wisdom deduced from the above overviewed of both 2007 and 2015 elections in Nigeria suggest that, there were no remarkable difference in the pre-election environment, intra party conflict, level of anticipated electoral violence, INEC level of preparation and its challenges, unsettled election related courts cases in the pre-election period, political party and their respective candidates' mindset towards election among others. Thus, simply implies that, there are other factors accountable for the difference in the quality and outcome of both elections which needed to be investigated.

\subsection{Leadership question and the Implications for Free and Fair Election}

Nigeria has experienced four consecutive changes of political leadership (presidency) within the space of five conducted presidential elections since the inception of the Fourth Republic in 1999. Similarly, within the same period the Independent National Electoral Commission (INEC) a body saddled with the responsibilities of electoral conduct and management in Nigeria has also witnessed series of leadership changes since its establishment in 1998: follow by the appointment of Justice Ephraim Ayo Apata in 1998-2000 as a pioneer chairman, Dr. Abel Guobadia 2000-2005, Prof. Maurice Iwu 20052010, Prof. Atahiru Jega 2010-2015 and the new Chairman Prof. Mamud Yakubu 2015 till date. Importantly, the 2007 and 2015 elections marked a turning point in Nigeria political history: the 2007 election was the first election which smoothly ushered a transfer of power from one elected government to another; however, the elections were massively criticized for irregularities and unprecedented rigging both by Nigerians and international communities. On the other hand, the 2015 elections were also considered as a test for democratic stability in Nigeria, as this elections recorded the first time the incumbent was defeated and openly accepted such defeat. Meanwhile, the 2015 elections were widely applauded: its conducts and outcomes were equally considered to be transparent and fair despite some critical challenges. Above all, the success of the 2015 elections in Nigeria was largely attributed to the initiatives and the leadership style of the INEC Chairman by many Nigerians and some international stakeholders despite the presence of critical determinant factors within the context of political leadership which made the success of the 2015 elections possible.

For instance, Udu (2015) asserted that the success of the 2015 election may well be attributed to the innovations of the INEC chairman Professor Jega, evidenced in the introduction of the PVC and the card reading machine, aimed at checkmating rigging, impersonation and related electoral malpractice. In the same vein, Prof. Solomon Akinboye, then Head of Department of Political Science, University of Lagos, also stressed that Prof. Jega has been tested to be a man of integrity and credibility, that he has instituted a very sound electoral system in Nigeria (venturesafrica.com/61984). George Onmanya a reporter/writer of Sahara Reporter, maintain the same opinion that history has been made by Prof Jega for decade to come in the story of Nigerian democracy: the 2015 elections' story will be incomplete without due reference to the chief electoral umpire, Prof. Jega. The same view was shared 
by Mr. Aigboje Ai-Imoukhuede, a former managing Director of Access Bank Plc and founder of Africa Initiative for Governance, he stated that they celebrate Prof Jega who had made history in Nigeria by conducting a free and fair elections in 2015 and has made history in Africa (www.thisdaylive.com/jega-nigeria).

Based on the forgoing explications, it is instructive to note that, while 'the theory of democracy is based on the principle of ruling by the people, in the real practice, it is the leaders who rule the people in a manner not altogether different from the princess and potentates of times past' (Lord, 2003), it is important to note that in a democracy political leadership do not only matters; they matters to a great extent. Indeed, without reducing politics to personalities or denying the fundamental causal significance of events, structures and processes, it seems scarcely credible to suggest that leadership is unimportant in the modern democracies. For instance, if Nigeria as a country has been blessed with selfless and genuine democratic political leaders since her independence in 1960, then it would be logical to conclude that socio-political and economic situation in Nigeria would in some respects be significantly different from the way we find it now: to the extent that the process and outcome of election could still be credible without necessarily maintaining permanent members of the Commission ((INEC National Commissioners and Resident Commissioners)) including its chairman, provided Nigeria is able to institutionalize credible method of building political leadership.

The next question is what actually makes the real difference between the 2007 and 2015 elections in Nigeria against the rhetoric of performance or non-performance of INEC under one Chairman or the others given different political scenarios that surrounded both elections?

Perhaps, the answers to the above question will raise other fundamental questions as follows: were 2007 and 2015 elections chaired by Prof. Maurice Iwu and Prof. Attairu Jega conducted under the same political leader/president? If the answer is 'no', what are the differences in terms of political atmosphere, leadership disposition to power, leadership respect for the rule of law and leadership will to conduct the free and fair election between 2007 elections under former President Olusegun Obasanjo and 2015 elections under former President Goodluck Jonathan?.

Contrary to the opinion expressed in the report on INEC by CODESRIA \& PAS's project on Modeling Success: Governance and Institution building in West Africa that, the success or failure of any electoral commission is not only dependent on the degree of availability of the requisite human, material and infrastructural tools at the disposal of its staff to work, but also on the quality and style of its leadership in terms of competence, capacity, procedural mechanism for decision-making and organizational and strategic ability. This study argues otherwise that, irrespective of the quality, competency, procedural mechanism for decision making and strategic ability of INEC chairman in position, the top-most political leadership or president's disposition to power, the rule of law and whether they are interested in re-contesting election or not are critical factors that could determine the success or failure of any electoral commission, given the nature of Nigerian politics and the prevalence institutional weakness.

In the prelude to Obansanjo's administration in 1999 which marked the advent of the Fourth Republic in Nigeria, the legacy of military rule has impeded on the development of civility in political leadership and hampered the emergence of a democratic culture needed for political development and overall wellbeing of Nigerians and the nation at large. This period was characterized with seat tight syndrome to power, weak political institutions, gross abuse of the rule of law, widespread corruption, wide spread poverty, weak economy, infrastructural decadence, and human rights abuse. However, some of these pathological vestiges were carried into the new Fourth Republic; prevalent among these pathologies is the military mentality syndrome of seat-tight approach to power which manifested in Obasanjo's negative approach to 2007 general elections and the rule of law in Nigeria.

For instance, in the build up toward the 2007 elections, so much was expected from the government and INEC particularly, on the aspect of delivering free, fair and credible elections, given the lessons learnt from the 2003 elections. However, the 2007 exercise was not any different. Perhaps the most worrisome aspect were several disregard for court rulings on the cases of illegal substitution and disqualification of candidates after party's primary elections particularly, by then national ruling party-Peoples Democratic Party (PDP) on which courts had reversed to status-quo in its ruling but either the party did not complied or partial complied to the court rulings; another dismal is the delay 


\section{Dr. BADMUS, Bidemi Gafar}

in the disbursement of funds to INEC by Obasanjo government in an attempt to manipulate INEC, which eventually hindered election preparedness such as procurement of both sensitive and nonsensitive election materials, organize specific strategic training for INEC core staffs, recruitment adequate number and training of ad-hoc staffs. According to CODESRIA \& PAS's project on Modeling Success: Governance and Institution building in West Africa, the delay impacted negatively on the overall capacity of the Commission to effectively manage the electoral process, thus compromising its performance and bringing it into disrepute before the Nigerian electorate.

In the same vein, the report of International Crisis Group (2007a:13) revealed that, in October 2006, the chairman raised alarm that the Commission was having difficulties withdrawing money from banks due to "administrative rascality" and delays within the Central Bank, the Budget Office and the Due Process Office, all resulting in the rejection of cheques issued by the Commission. While the arguments advanced by these offices that they acted in the need for prudence and accountability in funds management especially, in the context of Nigeria's prevalent history of corruption in public procurements, revelations on the flawed elections suggest that the delay in the release of funds to INEC was politically contrived to manipulate the Commission and the electoral process (Ibid.:14). According to INEC (2004:69-70), the late release of funds and shortfall in the funds released as against the approved in the Appropriation Act posed a considerable challenge to the Commission's planning and implementation efforts. More often than none, the shortfalls mostly affected the overheads cost, electoral and capital expenditures of INEC which is very crucial to successful conduct of elections.

Given, economic and population importance of Nigeria in Africa, INEC usually have access to aids and grants from international communities, donor agencies and other democracy promoter organizations to support INEC operations and training of both core staffs and ad-hoc staffs in order to help the country to groom its nascent democracy and prevent a reversal to undemocratic ruling. As rightly observed by Rotberg (2007:15), it is in view of the above that the United States, the United Kingdom, the European Union and several other groups, including the financiers of the Joint Donor Basket Fund (JDBF), funded processes that provided technical capacity-building assistance to INEC during the 2003 and 2007 elections. The outcome of the 2007 elections has also cast doubt on the impact of such contributions because, clearly, development partners were unable to impose effective delivery conditionalities on INEC.

The Obasanjo' third term truncated agenda also influenced his approach toward the 2007 elections: the failure of Obsanjo's third term agenda was a clear indication that he would not be re-contesting presidential election in 2007, this fostered his resentment attitudes toward electoral process and INEC' operations to the extent that Obasanjo embarked on spoiler game by feeding unpopular candidate for presidential race under the ruling party against the general interests of majority of his party caucus. Besides that, as a way of retaliation against the oppositions and some of his party members that work against his third term agenda, he openly declared that 2007 elections is a "Do or Die Affairs." for the People's Democratic Party (PDP). In the end he was able to back his words with negative actions at the detriment of credible elections and making the vote of electorates to counts. However, in the post 2007 elections INEC and its Chairman were mostly criticized for aiding and albeit electoral frauds.

The conventional wisdom deduced from the foregoing explications is that, there is no way INEC and its chairman could have performed any better given the unfathomable obstacles created for the successful conduct of election by the serving political leader or president at that period. This assertion was further buttressed by then former Chairman of the National Electoral Commission (NEC), Professor Humphrey Nwosu (2006) in the interview granted to (This Day, Saturday, January 14, 2006, pp. 53), when he stated that the difficulties and challenges facing the leadership of any electoral commission in Nigeria especially if somebody has to do it. Remember it is a difficult position for any Nigerian; no matter...his/her integrity, no matter his/her formal professions.... You can come with the best of intentions, but circumstances beyond your control may push you if you're not firm into one direction or the other.

The leadership approach toward the 2015 elections in terms of former President Jonathan's disposition to power, his commitment toward free and fair election and the attitude towards the rule of law: to some extent marked a turning from anomalies approach to the 2007 elections by former President Obasanjo. 


\section{Financial Adequacy of the 2015 General EleCtions}

On the financial aspect of election, over N114bn was spent on the 2015 general election by the government: the sum of N114, 058,943,747.48 was appropriated for the general elections (INEC 2015 Post-Election Report). While over 108.9bn was appropriated for the INEC for the general elections between 2014 and 2015, the estimated financial assistance from development partners was put at N5, 207, 269, 433. 55bn. This N5.2bn came through sponsorship of workshops, seminars, conferences, enlightment programmes and engagement of consultants. The Report specifically stated that the 2015 general elections was funded from two major sources; first, from consolidated national budgetary appropriation, and second, the assistance from development partners. According to the breakdown of the funds appropriated for the elections: N4bn was appropriated for ad-hoc staff honoraria, transportation for ad-hoc staff was N4.6bn, feeding of security officials was put $\mathrm{t}$ N1.8bn, while feeding of election officials was N1.25bn. The presidential/governorship runoffs/other rescheduled elections got N15.7bn while N2.5bn was appropriated for procurement of utility and special utility vehicles.

It was stated in the Report that the cost of ballot papers was put at N8.4bn, and ballot boxes at N5.02bn. N1.68bn was appropriated for voting cubicles, while insurance of INEC staff and ad-hoc staff got N1.2bn. The Report further revealed that the monitoring of political parties primaries got an appropriation of N600m while monitoring of elections (local and overseas) got N500m, the Smart Card Readers (SCR), training and mock elections to test SCR got N4.179bn. Electoral services wide vote got N2.5bn, while professional fees and expenses for external solicitors got N2.4bn.

On the other hand, the breakdown of funds from development partners according to INEC Post Election Report (2007), INEC claimed that it was supported with $\$ 21,316,005$ and 2, 099, 000 Euroabout N5,207, 260, 433. 55 to enable the Commission fund the 2015 general elections. The funds was pooled from Ford Foundation, United Nations Development Programme (UNDP), European Union (EU), the International Foundation for Electoral System (IFES) and Open Society Initiative for West Africa (OSIWA). The grants were targeted at specific electoral programmes aimed at promoting the successful conduct of the elections

Some of these grants include: $\$ 1 \mathrm{~m}$ from Ford Foundation for Business Process Redesign (BPR) and voter education. The UNDP/DGD gave a grant of \%1, 073, 005.67 for Election Management System (EMS), and training for security officials; another \$17, 552, 236 for sponsorship of INEC's engagement with relevant and strategic stakeholders among others. OSIWA extended a grant of $\$ 84$, 764. 00. to INEC for the prosecution of electoral offences and gazette of electoral regulations, civic education. Election Monitoring through the Yar'Adua Center was funded by a grant of $\$ 1.6 \mathrm{~m}$ from the Mac Arthor Foundation. International IDEA gave 209, 900 Euro for preventing conflict and electoral violence.

Based on the foregoing, and given the key roles of funds in the successful planning, execution of programmes, operations and conduct of elections, the 20015 elections is by far stand a better chance to be well conducted and more successful than the 2007 elections: this is by no wishful thinking but by the concerted commitment of former President Goodluck Jonathan to support INEC with adequate funds and ensure that there were no hindrances to access the funds by INEC from the Central Bank of Nigeria. Thus without adequate funding of INEC by the government as witnessed in 2003 and 2007 elections, there is little any INEC chairman can achieve irrespective of his/her level of integrity, initiatives and professional experiences.

\section{Leadership Disposition to Power and the Rule of Law during the 2015 Elections}

The former President Jonathan's disposition to political power particularly, the approach to his reelection ambition in 2015 was more democratic than that of former President Obasanjo successorship ambition in 2007: where Obasanjo declared the 2007 elections as 'do or die' affairs for himself and the People's Democratic Party. Jonathan tolerated the opposition parties and openly declared that he was willing to accept the outcome of preisential election irrespective of the winner. In the end, Jonathan openly conceded the defeat to his opposition as incumbent president for the first time in Nigeria political history and even before the official announcement of the presidential election result; he had congratulated his opponent, the winner of the election Muhamadu Buhari with a total number of 15,424,921 votes as against Goodluck Jonathan's 12,853,162 votes (INEC website). Thereafter, he 


\section{Dr. BADMUS, Bidemi Gafar}

also decided not to challenge the presidential election result in court: a process which would have hinder the success of the 2015 elections.

Jonathan heroic commitment was further buttressed by the INEC Post-Election Report in explaining why the 2015 presidential election was credible, it was unveiled by then acting INEC chairperson. Mrs. Amina Bala Zakari, that what stood out bold relief about the 2015 general elections is that for the first time since 1999, the outcome of the presidential election held on March, 2015 was uncontested in court, and, second, the historic concession made by the incumbent president, even before the official declaration of the presidential election result by the commission.

Given the foregoing explications, without Jonathan willingness to accept the outcome of presidential election in 2015 and his determination to give INEC a free hand to carry out its constitutional responsibilities without undue interference, it would have been impossible for INEC chairman to conduct free and fair election no matter how good were his plans and intentions. Indeed, it is interesting to note that former President Goodluck Jonathan not only accepted the results and conceded defeat; he even said that the credibility of the elections was one of his achievements for he has fulfilled his promise of free, fair and credible elections to Nigerians (Jonathan, 2015).

\section{Conclusion}

The prospects of free, fair and credible election in Nigeria lie on commitment and political will of the incumbent government to adherent to democratic principles, respect the rule of law and the determination to avoid undue interference with INEC operations. This schism was what makes the difference between the conduct of the 2007 and 2015 elections. In essence, the leadership approaches towards both the 2007 and 2015 elections have actually made the difference in terms of INEC performance/non-performance, credibility/non-credibility of election and the successful/nonsuccessful conduct of both elections under this study. For instance, the 2015 elections in terms of former President Jonathan's disposition to power, his commitment toward free and fair election and the attitude towards the rule of law: to some extent was a breakaway from 'do or die' politics and undemocratic approach towards the 2007 elections in Nigeria by former President Obasanjo.

In general, the success of the 2015 elections should be view as collective efforts of all Nigerians, including INEC chairman and the entire INEC workforce in consolidating our democracy. While in particular, the success and credibility of the 2015 presidential elections would not have been possible without the concerted efforts of the former President Goodluck Jonathan to adequately funded INEC, to avoid undue interference in INEC affairs during election and his heroic decision to concede defeat and decided not to contest the presidential election result in court: a process which could have ended in unprecedented level of violence and either prevent or prolong smooth transfer of power from one elected president to another.

\section{REFERENCES}

Eghosa, Osaghae, (2002). 'Crippled Giant Nigeria since Independence' PEFS; University of Ibadan, Nigeria.

Beetham David (ed.) (1994). 'Defining and Measuring Democracy', London Sage.

Inkeless Alex (ed.) (1991). 'On Measuring Democracy: Its Consequences and Concomitants'. New Brunswick: N.J. Transaction.

Eskor Toyo (1994) 'Crises of Democracy in Nigeria: Comments on the Transition From Babangida Regime’ Ahmadu Bello University Press Ltd: Zaria.

Lewis Arthur (1965) 'Politics in West Africa' London: George Allen and Unwin

Schumpeter, J. (1976) ‘Capitalism, Socialism and Democracy' London: Allen and Unwin.

Joseph, Richard (1987). Democracy and Prebendal Politics in Nigeria: The Rice and Fall of Second Republic. London: Cambridge University Press

Wanyande, P (1987). 'Democracy and the One-Party State: The African Experience' in W. Oyugi and A. Gbonga , (eds). Democracy Theory and Practice in Africa, Nairobi: Heinemann. P. 54

Nzongolo Ntalaja (1997). 'The State and Democracy in Africa' Cited in the 'State and Democracy in Africa' Ntalaja and Vargaret Lee (eds.) Harare AAPS Books

Ayoade, J. A. A. (1999). 'Aims and Objectives of Election Monitoring', in Ayoade. J.A.A. (ed) Handbook of Election Monitoring in Nigeria. Ibadan: Vantage Publishers Ltd. P.16. 
Graft, D.W. (1979) 1979 Election: The Nigeria Citizens Guide to Parties, Politics, Leaders and Issues. Lagos: Daily Times

Ayoade, J. A. A. (1999) op cit

Peele, G. (2005). Leadership and Politics: A Case for a Closer Relationship? Leadership, 1, 2, 187204

Seteolu, D. (2004), 'The Challenge of Leadership and Governance in Nigeria: The Constitution' in Journal of Constitutional Development, Centre for Constitutionalism and Demilitarisation (CENCOD), vol. 4(2), June, pp. 2-4

Chemers, M. M. (2002). 'Cognitive, Social, and Emotional Intelligence of Transformational Leadership: Efficacy and Effectiveness' in R. E. Riggio, S. E. Murphy \& F. J. Pirozzolo (eds.), Multiple Intelligences and Leadership. Mahwah, New Jersey: Lawrence Erlbaum Associates.

Dahl. R. A. (1989) 'Democracy and Its Critics'. New Haven. CT: Yale University Press.

Jinadu, Adele (2008) 'The Problem of Electoral Reform in Nigeria: Context and Possibilities' in Electoral Reforms in Nigeria: Preceedings of a National Workshop. S.O Akinde and A.T. Simbine (eds) New World Press, Ibadan.

EU-Election Observation Mission, (2007), Final Report: Presidential, National Assembly, Gubernatorial and State House of Assembly Elections in Nigeria. Retrieved from:http/: www.eeas.eropa.eu/ human_rights/election_observation/Nigeria/final_report_en.pdf. Institute for Democracy in South Africa (IDASA) (2007), Conflict Tracking dossiers and meetings

Aiyede, E. R. (2007), Electoral Laws and the 2007 General Elections in Nigeria, Journal of African elections special issue; Nigeria's 2007 General Elections. volume 6, Number 2. October.

Przeworski, Adam. (1991). Democracy and the Market: Political and Economic Reforms in Eastern Europe and Latin America. New York: Cambridge University Press. p. 10

Jinadu, Adele (2008) op cit

Richard Joseph (1983) Class, State and Prebendal Politics in Nigeria, $\mathrm{n}$ Journal of Commonwealth and Comparative Politics. Vol. XXL, No. 3.

Claude Ake (1994) 'Democratization of Development in Africa', Mathouse Press Limited.

Alex Gboyega (2003) Democracy and Development: The Imperative for Good Governance: An Inaugural Lecture, Vantage Publisher Ltd.

Eskor Toyo (1994) Crises of Democracy in Nigeria: Comments on The Transition From Babangida Regime: Ahmadu Bello University Press Ltd. Zaria.

Ehindero. S.G (2007) Securing the Electoral Process, in the Electoral Institute Journal Vol. 3 No. 1, INEC, Abuja

EU-Election Observation Mission, (2007) op cit

Anifowose, 2004

Bello, Imam (2008) Critical Areas Begging for Electoral Reform in Nigeria. in Electoral Reforms in Nigeria: Proceedings of a National Workshop. Akande and Simbine (eds) NISER, Ibadan.

Ibid.

Simbine, et al (2008) Electoral Reforms: The Way forward, cited in Electoral Reforms in Nigeria: Proceedings of National Workshop. Akande and Simbine (eds) NISER: Ibadan.

EU-Election Observation Mission, (2007), Final Report: Presidential, National Assembly, Gubernatorial and State House of Assembly Elections in Nigeria. Retrieved from: http/: www. eeas.eropa.eu/ human_ rights/ election_observation/Nigeria/final_report_en.pdf. Institute for Democracy in South Africa (IDASA) (2007), Conflict Tracking dossiers and meetings

Federal Republic of Nigeria, 2006, the Electoral Act 2006, Lagos: Federal Government Printer.

New York Times, January 25, 2015

Vanguard, PVCs: Distribution rate signals robust participation, March 24, 2015

Zaggi, H (2015). Transparent but Flawed Presidential Election, Citizens' Advocate, April 19, 2015

Ibid. p. 18 
Larry, E. Udu, (2015) INEC and the 2015 General Elections in Nigeria: Matters Arising, in Research on Humanities and Social Sciences. Vol.5, No.12 (www.thisdaylive.com/jega-nigeria)

Lord, C (2003) The Modern Prince: What Leaders Need to Know, New Haven: Yale University Press

CODESRIA \& PAS's project on Modeling Success: Governance and Institution building in West Africa.

International Crisis Group, (2007a), Nigeria's Elections: Avoiding A Political Crisis, Africa Report No. 123 Dakar/Brussels: International Crisis Group, 28 March. P. 13

Independent National Electoral Commission, (2004), Report of Activities, Abuja: Independent National Electoral Commission. P.69-70

Rotberg, R.I., (2007), Nigeria: Elections and Counting Challenges, CRS No. 27, New York: Council on Foreign Relations. P. 15

Interview with Prof. Humphrey Nwosu, ThisDay, Saturday, January 14, 2006, pp. 53

Independent National Electoral Commission, (2015), Post-Election Report on 2015 General Elections, INEC, Abuja: Nigeria.

Jonathan, G. (2015). "Official Statement by President Goodluck Jonathan after the Announcement of the Results of Presidential Elections" The News Magazine (April, 6-13). 